\title{
Optimization of Ore Production in Copper Mine
}

\author{
Eugenie Musonda Nyandwe* ${ }^{\circledR}$, Qinli Zhang, Daolin Wang \\ School of Resources and Safety Engineering, Central South University, Changsha, China \\ Email: *eugenianyandwe@yahoo.fr, zhangqinlicn@126.com, daolinw@csu.edu.cn
}

How to cite this paper: Nyandwe, E.M., Zhang, Q.L. and Wang, D.L. (2020) Optimization of Ore Production in Copper Mine. American Journal of Industrial and Business Management, 10, 61-74.

https://doi.org/10.4236/ajibm.2020.101005

Received: November 26, 2019

Accepted: January 6, 2020

Published: January 9, 2020

Copyright $\odot 2020$ by author(s) and Scientific Research Publishing Inc. This work is licensed under the Creative Commons Attribution International License (CC BY 4.0).

http://creativecommons.org/licenses/by/4.0/

\begin{abstract}
Mining activities are risky operations and represent a significant threat to capital investments. These activities, which require many years of evaluating the technical characteristics of the mineral deposit using the most appropriate method, also require an economic, safety, environmental or other evaluation. In this study, a feasibility study of copper production is proposed to determine the optimal production scale based on three production plans. The mining production scale is based on 4.5 million $\mathrm{t} / \mathrm{a}$ compared to other projects on the change in quantity, investment and engineering cost when the mining production scale is reduced to 3.5 million $t / a$ and increased to 5.5 million $t / a$. The results reveal that applying 4.5 million $\mathrm{t} / \mathrm{a}$ to the mining production project appears to be the optimal choice in terms of economic benefits, both after verification of the production scale in terms of annual decline rate and reasonable mine life. The result also shows that the production scale of 4.5 million $\mathrm{t} / \mathrm{a}$ is technically more feasible.
\end{abstract}

\section{Keywords}

Feasibility Study, Copper Production, Investment, Cost, Optimal Production, Decline Rate

\section{Introduction}

The determination of an ore production plan is one of the most crucial decisions affecting the viability of the mining project. Mining projects are generally made possible through the investment of massive funds. Indeed, the enormous initial costs, high operating costs and increasing risks make mining operations more challenging. However, effective management of these projects leads to significant profitability. In order to achieve good results, adequate planning is necessary and indispensable to maximize the value of the project (Kendrick, 2015) [1]. Planning is a decision-making process in which a vision of the company's situation is anticipated, and the means to achieve it are defined (Bak, P., 2012) [2]. 
Planning designs the expected future state, as well as the search for alternatives and the adequacy between the right activities and the future. The objective of each plan is to ensure the effective achievement of the stated objective. A plan should identify the measures leading to the desired objective and report on the risk. Financial planning, however, refers to an ongoing process of specifying how to achieve financial objectives. This is a crucial element of a company's planning cycle since the main objective of the company's activities is to maximize the market value of its capital and reserves (Banerjee, 2000) [3]. For this reason, a feasibility study must be carried out to determine the best production plan.

Elaboration of a feasibility study specifying how and with what resources the objectives of the evaluation can be achieved in terms of methodology. Mining operations should have production goals that are feasible and compatible with the system capacity (Rodovalho and Cabral, 2014) [4]. The feasibility study by a rough estimate of needs and costs in order to have an idea of the general budget is necessary to avoid precisely quantifying all needs and focus only on the most strategic ones. Miao et al. (2010) [5] used the method of solid filling in fullymechanized coal mining (SFFMCM) and pointed out the difficulties in developing the technology. They found that by using this technology not only can achieve the solid stowing to control strictly strata movement and ground subsidence prediction but also can achieve the economic benefit with high production and high recovery and environmental benefit. Mackenzie and Cusworth (2007) [6] present a framework for the conduct of "feasibility studies" and provide guidance to minimum standards and best practices. They assess that the feasibility study process must, therefore, demonstrate that not only have the technical issues been satisfactorily addressed but also that the broader commercial, economic and social issues have been considered in the development of a comprehensive business plan.

There are many different types of evaluations, each adapted to a different audience or targeting specific objectives. In this article, we will discuss the use of economic evaluations as a method of determining the efficiency of a program among the three existing programs, as well as identifying the needs and costs required to carry out the project. The economic evaluation provides criteria for choosing among several strategies. The economic evaluation also seeks to identify ways to use limited resources effectively.

In this feasibility study on optimizing copper ore production, first, we will analyze the copper ore production capacity of the Mujicun copper mine (Hebei province, China) base on the production plans of 3.5 million t/a, 4.5 million t/a, 5.5 million $\mathrm{t} / \mathrm{a}$. Then, after the comparison of the three production plans, the optimal production plan will choice in terms of investment, cost, engineering quantity, engineering complexity, and economic advantage.

\section{Background}

\subsection{Overview of Chinese Copper Industry}

China is a country with huge copper needs. The manufacturing and construction 
industries require large quantities of copper. In addition, copper, like oil, is a depleting resource (Liu et al., 2010; Karwowska et al., 2015) [7] [8]. More than 90\% of modern industrial companies require copper products and copper has already become an important strategic national security resource for both the economy and society. While in the past, industrialization and infrastructure construction processes required huge volumes of copper, today everything has changed, manufacturing industry volumes are gradually decreasing. China's copper stocks are enabling to reduce the high production activity. The Chinese economy faces a significant shift in its growth model, with GDP growth slowing down. All these factors have contributed to the formation of strategic copper stocks in China, which will be beneficial when copper prices rise (Brininstool, 2019) [9].

China, the second-largest copper producer, is set to significantly reduce its supply of red metal after its highest level of copper production in 2016, from $1,900,000$ tonnes to $1,600,000$ tonnes in 2018. In 2016, to contain its overcapacity and halt the fall in prices, ten major Chinese copper producers-including the Jiangxi Copper and Tongling smelters-have decided to reduce their total supply of red metal by 350,000 tonnes in 2017 . These ten companies represent about $70 \%$ of China's copper production, and the reduction they have committed to is equivalent to about $4.5 \%$ of the country's annual supply.

Base metal prices traded on the London Metal Exchange (LME) have recently declined, as the slowdown in Chinese activity has worried the markets. Copper, aluminum, tin, nickel, and zinc all declined. Moreover, despite its position, China does not have sufficient copper resources. Insufficient copper and the annual increase in production and consumption has led to a shortage of copper supply, while copper concentrates and refined copper are largely dependent on imports (Li et al., 2017) [10]. Chinese ores have a low grade and are not very rich compared to these main competitors Chile and Peru whose average porphyry copper grade is $(0.9 \%)$ and $(1.6 \%)$ respectively, compared to $0.55 \%$ for China (Wang, 2004) [11].

\subsection{Study Area}

\subsubsection{Mujicun Mine}

Mujicun mine is located in the north part of China and is one of the longest-sized $\mathrm{Cu}(\mathrm{Mo})$ deposits under exploitation in Hebei province. The deposit is an underground mine. The Mujicun porphyry $\mathrm{Cu}(\mathrm{Mo})$ deposit is a type of porphyry skarn where the predominant copper mineralisation is copper sulfide occurring as chalcopyrite. The copper ore from the Mujicun mine is characterized by its low grade. Mujicun deposits contain 36 ore bodies, including 23 porphyry ore bodies and 13 skarn ore bodies. According to the spatial location of the ore body, it can be divided into two ore belts, the upper and lower ore belt. The upper ore belt is the principal area of exploitation and includes 31 ore bodies. The analysis of Mujicun's copper ore reported in Table 1 shows that the lower ore belt has five orebodies and the copper resources of the main orebodies account for $98 \%$ of the total copper resources. 
Table 1. Mujicun Copper ore analysis results.

\begin{tabular}{ccc}
\hline Ore type & Grade $\left(10^{-2}\right)$ & Recovery (\%) \\
\hline Primary copper sulfide (Hypogene) & 0.27 & 86.82 \\
Secondary copper sulfide (Supergene) & 0.009 & 2.89 \\
Oxide copper & 0.014 & 4.50 \\
Free copper oxide & 0.018 & 5.79 \\
Total copper & 0.311 & 100.00 \\
\hline
\end{tabular}

The Mujicun copper mine is characterized by large low-grade reserves based on the principle of obedience to the scale of benefits for the demonstration of the scale of production. The production scale is an important economic and techni$\mathrm{cal}$ indicator that affects the economic benefits of the mine and must be reasonably determined. If the production scale is determined to be too large relative to the mining reserves, it is difficult to recover the investment within the service life of the mine, and therefore, there is not enough opportunity to adjust the defects in the production of the mine and factory before the reserves are consumed. Conversely, if the production scale is too small, the rate of return on production is not high, and the payback period is prolonged. If it is expanded after it is put into production, the investment required is much higher than that of one of the production scales. Therefore, a feasibility study must be reasonably determined.

\subsubsection{Alternative Industrial Site Schemes}

The Mujicun mining area selected the following two selection engineering industrial site layout plan:

Scheme I: The sub-well is located outside the surface movement boundary between the 76 - 86 line west of the western valley of the deposit, arranged in turn along the north-south direction of the hillside, the length of the north-south length is about $465 \mathrm{~m}$, the widest point is about $216 \mathrm{~m}$, the narrowest point is about $86 \mathrm{~m}$, covers an area of about $39,928 \mathrm{~m}^{2}$ and does not need land acquisition. The main well is arranged on the hill bag in the northern part of the ball group factory, the field landmark is $815 \mathrm{~m}$ high, requires a small amount of land acquisition, land acquisition type is mountainous (see Figure 1).

Scheme II: The main well layout ball plant on the northeast hill package, the wellhead site landmark height of $815 \mathrm{~m}$, the main well industrial site needs a small amount of land acquisition, land acquisition type is mountainous. The sub-wells are arranged along the northwest moving boundary of the mine, and the structures built in the area are mainly abandoned workshops of the original Yanyuan Iron and Steel Company, which do not require land acquisition, and the high sorghum site landmarks are $780 \mathrm{~m}$ and $758 \mathrm{~m}$ respectively. The main sub-well industrial site is located in a slab-like terrain, the highest elevation of $815 \mathrm{~m}$, the lowest elevation of $758 \mathrm{~m}$, the northwest direction of the plant is about $170 \mathrm{~m}$, the narrowest width of $85 \mathrm{~m}$, the northeast direction of about 462 m (see Figure 2). 


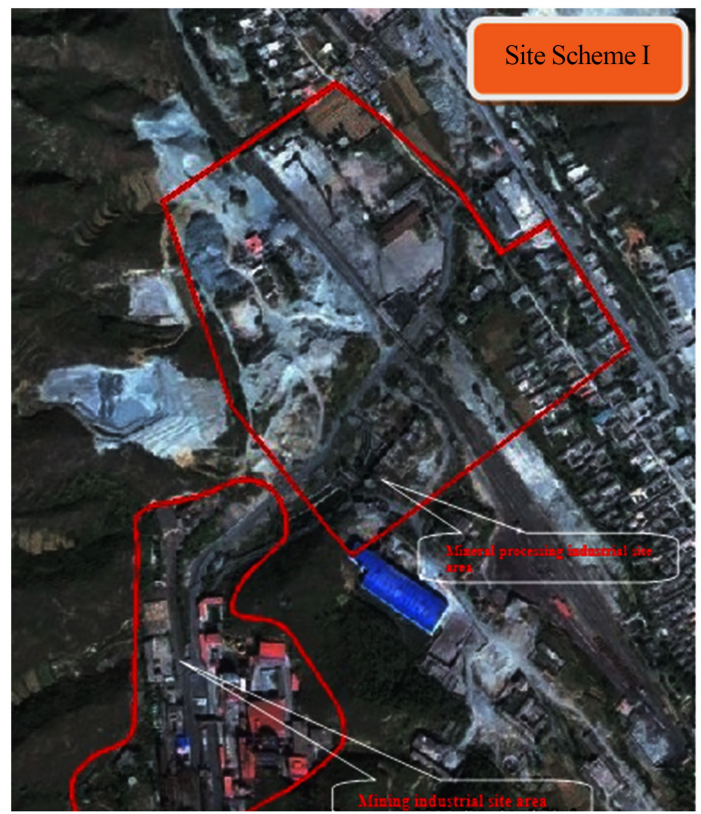

Figure 1. Industrial site scheme I.

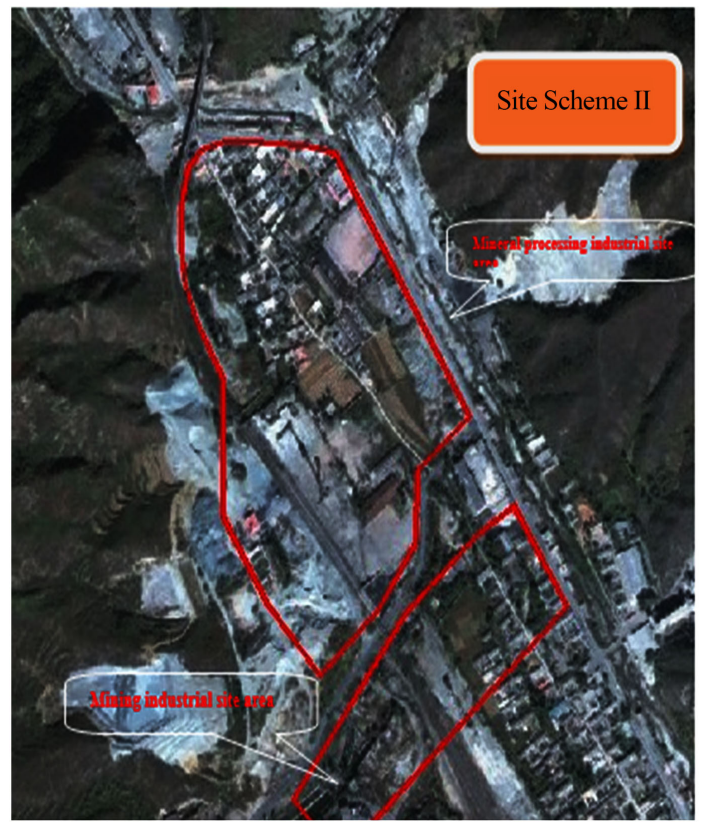

Figure 2. Industrial site scheme II.

\section{Economic Evaluation}

Economic evaluation is one of the analytical tools available to decision-makers (Siebert, 2003; Sculpher et al., 2006) [12] [13]. In economic evaluation, analytical techniques are applied to identify, measure, assess, and compare the costs and consequences of two or more alternative programs or interventions. The economic evaluation shows whether the benefits of a proposal or change exceed its costs, which option has the highest net benefit or which option is the most cost-effective if the benefits are equivalent to the distribution of costs and bene- 
fits among stakeholders.

There are several advantages to conducting an economic evaluation:

1) It requires systematic consideration of the costs and outcomes that could be generated by the implementation of a specific program or intervention;

2) It allows for an objective comparison of alternatives (competing interventions or programs); and

3) It provides information that decision-makers can use to make the most of mining financing. Different types of evaluation can be applied to proposals. These range from financial evaluations to those that include broader community impacts, such as economic and social evaluations. In this study, an economic evaluation will focus on costs and investments.

\subsection{Costs}

Costs are the different values of the resources used to produce a good or service. The success of any economic evaluation requires the creation of a comprehensive cost inventory. The cost of resources is obtained in many ways. For example, it involves obtaining the market price of all goods and services that are part of a program or intervention. The market price is a convenient measure of cost because it is easy to know the price of all resources and exchanges are based on monetary value.

According to Wiest (1964) [14] when resources are limited, basic habitual concepts lose their normal meaning. The resources devoted to the project are not available for the implementation of the chosen project. In the mining industry, each mining operation is unique and the results of cost estimation are therefore extremely complex. It would be challenging to develop a standard method that is appropriate for each mine, as costs can vary considerably from one operation to another depending on the physical characteristics of the deposit or site and operational parameters.

However, all types of operations have something in common. For example, direct costs correspond to expenses related to the cost of the project (labour, equipment, materials, and subcontractors). Indirect expenses are expenses that are not related to the cost of the project, such as overhead, capital assets, various expenses, insurance or administrative costs, as well as temporary work that is not related to the cost of the project (Posnett and Jan, 1996) [15].

\subsection{Investment}

An investment is an individual or collective decision, after a thorough analysis, to invest or lend money in a property, securities with sufficiently low risk, and the potential to generate returns over a given period. Cord (1964) [16] defines investment decision as an optimal approach to capital investments with uncertain returns, under limited funding conditions, and a constraint on the maximum average variance allowed in the final set of investments. The risk factor is inherent in any productive investment project because the expected gain, namely the excess of cash inflows over outflows, is merely expected and uncertain. In- 
deed, any projection over time is subject to uncertainty (Heuberger, 2005) [17]. Investment concepts are dynamic, and it is essentially a process of buying and installing assets or the money spent on them as a whole. Also, the project is considered an activity for which we will spend money in anticipation of returns and which logically seems to lead to planning, financing, and implementation as a unit.

In the mining industry, capital investment project involves-exploration expenses (mapping, drilling, sampling); costs of acquiring real estate; mine development costs; plant and equipment costs, including mining equipment, processing and grinding equipment, building, and structure, etc; legal Environmental Impact Statement (EIS); working capital; development capital. The purpose of these investments is to obtain, over a more or less long period, financial or non-financial benefits through the production of goods or services. Therefore, although the notion investment applies to both the act of investment and the result of that act, any productive investment project can only be significant and justified if the immobilization of funds in this way allows a significant financial return to be expected in future years. Given the enormous implications (financial, time), companies must analyse and compare several projects before collecting the best possible, i.e., an alternative evaluation is necessary in advance according to the specific characteristics. Any productive investment project is confronted with time factors that remain decisive in assessing the profitability of a project. The investment may be made straight away or delayed for some period (Campbell, 2002) [18].

\section{Construction Scale and Description of the Methodology}

1) According to the occurrence of Mujicun copper ore body, the completed $0.8 \mathrm{~km}^{2}$ ore body is divided into two-scale of the mining area. The first phase of the mining area covers the upper ore belt, the ore body mineralized over $+100 \mathrm{~m}$; the resources are estimated at 131.691 million tonnes. The second phase mining area covers the upper ore belt and the lower ore belt, the ore bodies mineralized $0-100 \mathrm{~m}$ (the upper ore belt $-100 \mathrm{~m}$ and the lower ore belt $0 \mathrm{~m}$ ). The first scale mining area is the core research of our project, and the ore body is between 100 $\mathrm{m}$ and $580 \mathrm{~m}$.

2) In this design of the feasibility study, according to the Taylor experience formula recommended in the second edition of the SNME Mining Engineering Manual of the United States, the production capacity of the mine within the first and second phase slots of the Mujicun Copper Mine is compared with the production capacity of the mine within the scope of the project: the production scale of the mine is based on 4.5 million $\mathrm{t} / \mathrm{a}$, and the reduction of the mine production scale to 3.5 million $\mathrm{t} / \mathrm{a}$ or the increase of the mine production scale to 5.5 million $\mathrm{t} / \mathrm{a}$ when the main project volume, investment and cost changes are sought to find the best economic efficiency.

3) According to the characteristics of low grade, large reserves and large buried extension of the copper mine in Mujicun, the scale scheme of the project is 
demonstrated in accordance with the principle of scale obedience to efficiency. The scale of production is an important economic and technical index that affects the economic benefits of mines, especially low-grade mines. If the scale of production relative to the mining reserves determined to be too large, the mine service life is difficult to recover the investment. Before the consumption of reserves, there is not enough opportunity to adjust the mine and plant production defects; therefore, the purpose of the comparative demonstration of the scale scheme is to determine the optimal production scale through economic analysis.

4) The concentrate section is dense, and the second section is dehydrated with a ceramic filter. Tailings use a dense dewatering process. The mineralization process is the same for each capacity scale scheme, so the scheme focuses on investment and costs of different sizes.

\section{Results}

\subsection{Determination of the Scale of Construction}

A comparative chart of the comprehensive analysis programme leads to the following conclusions:

1) The first phase of the scale scheme project mining object is between $100 \mathrm{~m}$ and $580 \mathrm{~m}$ scale ore body, the scale scheme capacity of 3.5 million $\mathrm{t} / \mathrm{a}, 4.5 \mathrm{mil}-$ lion $\mathrm{t} / \mathrm{a}$ and 5.5 million $\mathrm{t} / \mathrm{a}$ when the first phase of the project mine service life is $40 \mathrm{a}, 32 \mathrm{a}$ and $28 \mathrm{a}$. Due to the low grade of mineral resources, the economic benefits of the mine after production in general, loan repayment pressure is greater, loan repayment period and investment recovery period is longer, as the benefit of the general large-scale-very large metal mines, service life in about $35 \mathrm{a}$ is more appropriate.

2) From Table 2, it can be seen that when the construction scale increased from 3.5 million t/a to 4.5 million t/a, the comparable investment in mining control projects increased by RMB 110.4663 million (US\$ 15.7052 million), and the comparable investment in mineral processing projects increased by RMB 98.2471 million (US\$ 13.969 million); when the scale increased from 4.5 million $\mathrm{t} / \mathrm{a}$ to 5.5 million $\mathrm{t} / \mathrm{a}$, the comparable investment in mining control projects increased by RMB 19.5416 million (US\$ 2.778 million), and the comparable investment in mineral processing projects increased by RMB 99.900 million (US\$ 14.204 million). The scale of construction increased from 4.5 million $t / a$ to 5.5 million $\mathrm{t} / \mathrm{a}$ when the investment increase was larger, so from an investment point of view, the scale of mine construction was determined to be 4.5 million t/a more reasonable.

3) 4.5 million t/a scale program and 3.5 million t/a scale program comparison. Mining projects mainly open up the amount of system engineering change is not much, but part of the project volume increased, the entire project volume, construction cycle and construction difficulty did not increase much, the mineral processing project plant is arranged outside the northern moving limit of the ore body, the area for the owner unit fixed assets, less land acquisition. 
Table 2. Comparison of investment and cost plans for different scale schemes.

\begin{tabular}{|c|c|c|c|c|c|c|c|c|}
\hline \multirow[b]{2}{*}{$\begin{array}{c}\text { Serial } \\
\text { number }\end{array}$} & \multirow[b]{2}{*}{ Name } & \multicolumn{2}{|c|}{$\begin{array}{c}\text { Schemes I } \\
(350 \text { thousand } \mathrm{t} / \mathrm{a})\end{array}$} & \multicolumn{2}{|c|}{$\begin{array}{c}\text { Schemes II } \\
\text { (450 thousand } t / a)\end{array}$} & \multicolumn{2}{|c|}{$\begin{array}{c}\text { Schemes III } \\
\text { (550 thousand t/a) }\end{array}$} & \multirow[b]{2}{*}{ Remarks } \\
\hline & & $\begin{array}{l}\text { Quantity } \\
\left(\mathrm{m}^{3}\right)\end{array}$ & $\begin{array}{c}\text { Investment } \\
\text { (Ten thousand } \\
\text { yuan) }\end{array}$ & $\begin{array}{l}\text { Quantity } \\
\left(\mathrm{m}^{3}\right)\end{array}$ & $\begin{array}{c}\text { Investment } \\
\text { (Ten thousand } \\
\text { yuan) }\end{array}$ & $\begin{array}{l}\text { Quantity } \\
\qquad\left(\mathrm{m}^{3}\right)\end{array}$ & $\begin{array}{c}\text { Investment } \\
\text { (Ten thousand } \\
\text { yuan) }\end{array}$ & \\
\hline I & Mining section & & & & & & & \\
\hline First & Comparable infrastructure & & & & & & & \\
\hline (First) & Comparable well engineering & & & & & & & \\
\hline 1 & Main well & $30,078.68$ & 3771.51 & $34,598.00$ & 4168.30 & $59,655.66$ & 7401.79 & \\
\hline 2 & $1^{\#}$ auxiliary shaft & $37,259.27$ & 4613.84 & $41,763.00$ & 5123.79 & $43,957.36$ & 5420.94 & \\
\hline 3 & $2^{\#}$ auxiliary shaft & $23,605.26$ & 2958.00 & $31,700.00$ & 3913.04 & $41,732.61$ & 5169.49 & \\
\hline 4 & Return air well & $35,678.02$ & 3915.82 & $43,060.00$ & 4847.46 & $49,953.66$ & 5699.35 & \\
\hline 5 & Slip system & $27,099.48$ & 6416.39 & $39,279.15$ & 7383.38 & $45,600.51$ & $10,028.65$ & \\
\hline 6 & Subtotal & $153,720.72$ & $21,675.55$ & $190,400.15$ & $25,435.97$ & $240,899.80$ & $33,720.22$ & \\
\hline (Second) & Ground civil engineering & & 2986.78 & & 3110.25 & & 4816.25 & Well tower \\
\hline 1 & Subtotal & & 2986.78 & & 3110.25 & & 4816.25 & \\
\hline (Third) & total & $153,720.72$ & $24,662.33$ & $190,400.15$ & $28,546.22$ & $240,899.80$ & $38,536.47$ & \\
\hline (Second) & mining machine & & & & & & & \\
\hline (First) & Lifting system & & & & & & & \\
\hline 1 & Main well lifting system & & 3359.91 & & 3912.25 & & 6930.42 & $\begin{array}{c}\text { Including } \\
\text { electronic control }\end{array}$ \\
\hline 2 & $1^{\#}$ Auxiliary well lifting system & & 1131.02 & & 1155.44 & & 1220.76 & $\begin{array}{c}\text { Including } \\
\text { electronic control }\end{array}$ \\
\hline 3 & $2^{\#}$ Auxiliary well lifting system & & 1050.12 & & 1094.32 & & 1162.22 & $\begin{array}{c}\text { Including } \\
\text { electronic control }\end{array}$ \\
\hline 4 & Subtotal & & 5541.05 & & 6162.01 & & 9313.40 & \\
\hline (Second) & Pit transport & & & & & & & \\
\hline 1 & Rail transport & & 2286.15 & & 2658.57 & & 3128.93 & \\
\hline 2 & Trackless transport & & 360.00 & & 540.00 & & 540.00 & \\
\hline 3 & Subtotal & & 2646.15 & & 3198.57 & & 3668.93 & \\
\hline (Third) & Crushing system & & 623.56 & & 2017.52 & & 2151.08 & \\
\hline 1 & Subtotal & & 623.56 & & 2017.52 & & 2151.08 & \\
\hline (Fourth) & Total & & 8810.76 & & $11,378.10$ & & $15,133.41$ & \\
\hline Third & Mining, auxiliary equipment & & & & & & & \\
\hline 1 & Mining equipment & & $12,473.60$ & & $16,755.00$ & & $21,588.60$ & \\
\hline 2 & Mining auxiliary equipment & & 1554.40 & & 1868.40 & & 2813.40 & \\
\hline 3 & Subtotal & & $14,028.00$ & & $18,623.40$ & & $24,402.00$ & \\
\hline Fourth & Total & & $47,501.09$ & & $58,547.72$ & & $78,071.88$ & \\
\hline Fifth & $\begin{array}{l}\text { Mining comparable } \\
\text { investment balance }\end{array}$ & $\begin{array}{l}\text { Scheme I } \\
\text { (ten thor }\end{array}$ & $\begin{array}{l}\text { II - Scheme I } \\
\text { usand yuan) }\end{array}$ & $11,046.63$ & $\begin{array}{l}\text { Scheme III - } S \\
\text { (ten thousan }\end{array}$ & $\begin{array}{l}\text { Scheme II } \\
\text { ad yuan) }\end{array}$ & $19,524.16$ & \\
\hline II & Processing, tailings & & & & & & & \\
\hline
\end{tabular}




\begin{tabular}{|c|c|c|c|c|c|c|}
\hline First & Selection of civil works & 8018.55 & & 9895.19 & $11,580.29$ & \\
\hline Second & Mineral processing equipment & $22,298.69$ & & $28,575.69$ & $34,060.58$ & \\
\hline Third & Tailings library project & 5189.70 & & 6860.77 & 9680.78 & \\
\hline Fourth & Total & $35,506.94$ & & $45,331.65$ & $55,321.65$ & \\
\hline Fifth & $\begin{array}{c}\text { Mineral processing } \\
\text { comparable investment } \\
\text { balance }\end{array}$ & $\begin{array}{l}\text { Scheme II - Scheme I } \\
\text { (ten thousand yuan) }\end{array}$ & 9824.71 & $\begin{array}{l}\text { Scheme III - Scheme II } \\
\text { (ten thousand yuan) }\end{array}$ & 9990.00 & \\
\hline III & Total comparable investment & $83,008.03$ & & $103,879.37$ & $133,393.53$ & \\
\hline IV & $\begin{array}{c}\text { Mineral processing } \\
\text { comparable investment } \\
\text { balance }\end{array}$ & $\begin{array}{l}\text { Scheme II - Scheme I } \\
\text { (ten thousand yuan) }\end{array}$ & $20,871.34$ & $\begin{array}{l}\text { Scheme III - Scheme II } \\
\text { (ten thousand yuan) }\end{array}$ & $29,514.16$ & \\
\hline $\mathrm{V}$ & Cost & yuan/t & & yuan/t & yuan/t & \\
\hline First & Mining manufacturing costs & 108.45 & & 105.20 & 104.88 & Annual average \\
\hline Second & Mineral processing cost & 55.22 & & 53.71 & 52.98 & Annual average \\
\hline Third & Expenses for the period & 28.85 & & 27.72 & 25.92 & Annual average \\
\hline Fourth & Total cost & 192.52 & & 186.63 & 183.78 & Annual average \\
\hline
\end{tabular}

4) 5.5 million t/a scale program and 4.5 million t/a scale program. Mining projects mainly open-up project changes significantly, the development project added a main well, the entire mine infrastructure project volume greatly increased, the infrastructure cycle extended, the mining project plant covers a large area, the northern area of the mining area is not enough, the need to occupy part of the arable land and floating villages, increased investment in the project, but also delayed the progress of the project. Therefore, from the point of view of project volume and engineering complexity, the construction scale of 4.5 million $\mathrm{t} / \mathrm{a}$ is more reasonable and feasible than the other two programs.

5) From Table 2, we can see that the construction scale increased from 3.5 million $t / a$ to 5.5 million $t / a$ process, the total cost with the increase of the construction scale gradually decreased, the decline gradually decreased and gradually slowed down.

In summary, while the costs of construction programme has been gradually reduced from 3.5 million t/a to 5.5 million $t / a$, the reduction in capacity costs from 4.5 million $\mathrm{t} / \mathrm{a}$ to 5.5 million $\mathrm{t} / \mathrm{a}$ costs is very limited, while the volume of infrastructure projects and infrastructure investment have increased significantly. Therefore, the 4.5 million t/a construction scale offers more economic advantage than the other two options and seems to be the optimal choice in terms of investment, cost, engineering quantity and complexity, so the scale of production of this design is determined to be 4.5 million t/a.

\subsection{Estimation and Testing}

Mujicun mine adopts the continuous working system, which an annual working of 330 days, 3 shifts/day, 8 hours/shift. The optimal production plan that will be 
applied for the verification is 4.5 million $\mathrm{t} / \mathrm{a}$. The economic and reasonable service life of the mine taking the minimum value of 25 a, and in this study, we use the first scale mining area the mineralized over $+100 \mathrm{~m}$.

\subsubsection{Verification of the Production Capacity According to the Annual Decline Rate of the Mining}

Verify production capacity at annual decline rate:

$$
V=\frac{A h(1-\beta)}{Q E \alpha}
$$

where: $V$ : Annual decline rate, $\mathrm{m} / \mathrm{a}$;

$A$ : Annual production capacity of mines, Million t/a;

$H$ : Middle height, m;

$B$ : Ore depletion rate, \%;

$Q$ : Middle ore volume, Ten thousand d;

$E$ : Geological influence coefficient, taken as 1 ;

$A$ : Ore recovery rate, $\%$.

The calculation results of the annual decline of each middle section are shown in Table 3. According to the current-controlled reserves, the first phase mining area is used base on the production scale of 4.5 million t/a. Only the annual decline rate of the middle section of $500 \mathrm{~m}$ is higher than the normal value, which indicates that the middle section can complete the 4.5 million t/a scale when only is mined together with the adjacent middle section. The main production section is $100 \mathrm{~m}-400 \mathrm{~m}$, the annual decline of the middle section is $13.28-19.55$ $\mathrm{m} / \mathrm{a}$, and the annual decline rate average is $16.24 \mathrm{~m} / \mathrm{a}$. According to statistics on the annual decline rate of the similar mine in China and the first phase of the Mujicun copper mining area designed with a production scale of 4.5 million t/a, the annual decline rate is within a reasonable range.

\subsubsection{Verification of the Production Capacity According to the Reasonable Service Life of the Mine}

Reasonable service life:

$$
A=\frac{Q E \alpha}{T(1-\beta)}
$$

\begin{tabular}{|c|c|c|c|c|c|c|c|c|}
\hline Section & $\begin{array}{c}\text { Resources/ } Q \\
(10000 \mathrm{t})\end{array}$ & $\begin{array}{c}\text { Recovery } \\
\text { rate/ } \alpha \\
(\%)\end{array}$ & $\begin{array}{c}\text { Depletion } \\
\text { rate/ } \beta \\
(\%)\end{array}$ & $\begin{array}{c}\text { Geological } \\
\text { impact } \\
\text { factor/E }\end{array}$ & $\begin{array}{l}\text { Production } \\
\text { capacity/ } A \\
(10,000 \text { t/a) }\end{array}$ & Height/h(m) & $\begin{array}{l}\text { Length of } \\
\text { service/T(a) }\end{array}$ & $\begin{array}{c}\text { Decline } \\
\text { rate/ } V(\mathrm{~m} / \mathrm{a})\end{array}$ \\
\hline $500 \mathrm{~m}$ & 775.97 & $85 \%$ & $8 \%$ & 1.0 & 450 & 100 & 1.59 & 62.77 \\
\hline $400 \mathrm{~m}$ & 2491.60 & $85 \%$ & $8 \%$ & 1.0 & 450 & 100 & 5.12 & 19.55 \\
\hline $300 \mathrm{~m}$ & 3626.87 & $85 \%$ & $8 \%$ & 1.0 & 450 & 100 & 7.45 & 13.43 \\
\hline $200 \mathrm{~m}$ & 3668.87 & $85 \%$ & $8 \%$ & 1.0 & 450 & 100 & 7.53 & 13.28 \\
\hline $100 \mathrm{~m}$ & 2605.81 & $85 \%$ & $8 \%$ & 1.0 & 450 & 100 & 5.35 & 18.69 \\
\hline
\end{tabular}

Table 3. Production capacity. 
where: $T$ : The economic and reasonable service life of the mine, taking the minimum value of $25 \mathrm{a}$;

Q: Phase I design mining reserves, $131.691 .1 \mathrm{Mt}$;

$E$ : Geological influence coefficient, take 1;

$A$ : Comprehensive recovery rate, $85 \%$;

$B$ : Depletion rate, $8 \%$.

The mine production capacity is verified according to the Mujicun mining reserves and the economic reasonable service life of the mine, and the production scale reaches $4870 \mathrm{Mt} / \mathrm{a}$. The $4500 \mathrm{Mt} / \mathrm{scale}$ meets the requirements.

\subsection{Determination of Mine Production Capacity}

By comparison with the multiple programmes, it is economically recommended to use 4.5 million t/a production scale. At the same time, according to the number of mines can be arranged, and according to the rate of decline in mining years, the mine economic reasonable service life to verify the scale of construction, the results of the verification also show that the construction scale of 4.5 million $t / a$ is technically feasible. Therefore, the production scale of this design is determined to be 4.5 million $\mathrm{t} / \mathrm{a}$.

\section{Conclusion and Recommendations}

\subsection{Conclusion}

In this study, three production plans of 3.5 million t/a, 4.5 million t/a, 5.5 million $t / a$, were part of the feasibility study on optimizing copper ore production. The object of this study was to find the optimal production scale of the target mine. The feasibility results of Mujicun copper mine were analyzed and compared. After the comparison of multiple production plans, the optimal production plan was choice in terms of investment, cost, engineering quantity, engineering complexity, and economic advantage. It is economically recommended to adopt a production scale of 4.5 million $\mathrm{t} / \mathrm{a}$. At the same time, according to the calculation of the number of panels that can be arranged in mine and according to the verification of the annual decline rate of mining and the reasonable service life of mine, the verification results also show that the production scale of 4.5 million $\mathrm{t} / \mathrm{a}$ is technically feasible. Therefore, the optimal production scale of $\mathrm{Mu}$ jicun copper mine is determined to be 4.5 million $t / a$, and it would be more reasonable to operate the mine for a lifetime of 25 a in this specific model study.

\subsection{Recommendations}

From the above scheme comparison, you can see:

1) Scheme I main well is closer to the original mine workshop of the selection plant, and the transportation cost of surface ore belt and the transportation cost of underground ore are significantly lower than the cost of scheme II;

2) Both scheme I and scheme II require the expropriation of part of the mountain, but scheme II requires the occupation of a large amount of agricul- 
tural land in some villages in Futu, and the cost of land acquisition and relocation is much higher than that of programme I;

3) Scheme II surface can be used with large area, flexible arrangement, scheme I surface can be used for a small area, compact arrangement;

4) Scheme I can be compared to part of the project investment than scheme II 5637.18 million yuan ( $\$ 801.28$ million) less and the annual operating costs of 2.8549 million yuan ( $\$ 0.4058$ million) less.

Comprehensive analysis, from the investment, cost and the future of southern mining convergence point of view, the main industrial site recommended the use of scheme I.

\section{Conflicts of Interest}

The authors declare no conflicts of interest regarding the publication of this paper.

\section{References}

[1] Kendrick, T. (2015) Identifying and Managing Project Risk: Essential Tools for Failure-Proofing Your Project. Amacom.

[2] Bak, M., Borkowski, P. and Pawlowska, B. (2012) Types of Solutions Improving Passenger Transport Interconnectivity. Transport Problems, 7, 27-36.

[3] Banerjee, A. (2000) Linkage between Economic Value Added and Market Value: An Analysis. Vikalpa, 25, 23-36. https://doi.org/10.1177/0256090920000304

[4] Rodovalho, E.D.C. and Cabral, I.E. (2014) Estimate of Hourly Productivity Applied to Elaboration and Implementation of Mining Plans. Rem: Revista Escola de Minas, 67, 221-227. https://doi.org/10.1590/S0370-44672014000200015

[5] Miao, X.X., Zhang, J.X. and Guo, G.L. (2010) Study on Waste-Filling Method and Technology in Fully-Mechanized Coal Mining. Journal of China Coal Society, 35, 1-6.

[6] Mackenzie, W. and Cusworth, N. (2007) The Use and Abuse of Feasibility Studies. AusIMM Project Evaluation Conference, Australasian Institute of Mining and Metallurgy, Melbourne, Australia.

[7] Liu, S., Wang, G.S. and Chen, Q.S. (2010) The Prediction of the Demand and Supply of Copper in China. China Mining Magazine, 8.

[8] Karwowska, E., Wojtkowska, M. and Andrzejewska, D. (2015) The Influence of Metal Speciation in Combustion Waste on the Efficiency of $\mathrm{Cu}, \mathrm{Pb}, \mathrm{Zn}, \mathrm{Cd}, \mathrm{Ni}$ and Cr Bioleaching in a Mixed Culture of Sulfur-Oxidizing and Biosurfactant-Producing Bacteria. Journal of Hazardous Materials, 299, 35-41. https://doi.org/10.1016/j.jhazmat.2015.06.006

[9] Brininstool, M. (2019) Remaining Mines were Either Small Leach Operations or Product Producers of Copper. Global Mine Production Increased by about $8 \%$ to 18.3 Mt. Minerals Yearbook: Metals and Minerals.

[10] Li, L., Pan, D.A., Li, B., Wu, Y., Wang, H., Gu, Y. and Zuo, T. (2017) Patterns and Challenges in the Copper Industry in China. Resources, Conservation and Recycling, 127, 1-7. https://doi.org/10.1016/j.resconrec.2017.07.046

[11] Wang, J. (2004) Prospects of Exploration and Development of Copper Resources in China. Scientific and Technological Management of Land and Resources, 21, 27-30. 
[12] Siebert, U. (2003) When Should Decision-Analytic Modeling Be Used in the Economic Evaluation of Health Care? The European Journal of Health Economics, 4, 143-150. https://doi.org/10.1007/s10198-003-0205-2

[13] Sculpher, M.J., Claxton, K., Drummond, M. and McCabe, C. (2006) Whither TrialBased Economic Evaluation for Health Care Decision Making? Health Economics, 15, 677-687. https://doi.org/10.1002/hec.1093

[14] Wiest, J.D. (1964) Some Properties of Schedules for Large Projects with Limited Resources. Operations Research, 12, 395-418. https://doi.org/10.1287/opre.12.3.395

[15] Posnett, J. and Jan, S. (1996) Indirect Cost in Economic Evaluation: The Opportunity Cost of Unpaid Inputs. Health Economics, 5, 13-23. https://doi.org/10.1002/(SICI)1099-1050(199601)5:1<13::AID-HEC182>3.0.CO;2-J

[16] Cord, J. (1964) A Method for Allocating Funds to Investment Projects When Returns Are Subject to Uncertainty. Management Science, 10, 335-341. https://doi.org/10.1287/mnsc.10.2.335

[17] Heuberger, R. (2005) Risk Analysis in the Mining Industry. Journal of the Southern African Institute of Mining and Metallurgy, 105, 75-79.

[18] Campbell, J.A. (2002) Real Options Analysis of the Timing of IS Investment Decisions. Information \& Management, 39, 337-344. https://doi.org/10.1016/S0378-7206(01)00101-X 